\title{
Refashioning Rawls as a true champion of the poor
}

\section{ABSTRACT}

Rawls champions the cause of the poor because of his strong moral sentiments about the eradication of poverty. I present these sentiments that he converts into normative elements of his theory of justice. However, the conceptual framework and intellectual resources that he uses to articulate these sentiments are inadequate. His sentiments against poverty cannot be accommodated neatly, simply, and coherently in his liberal theoretical framework. Also, I point out that his definition for the identification of poor people as the least advantaged members of society is not adequate. Therefore his theory is refashioned so that it can properly account for the fundamental interests of poor people. An alternative conception is presented to revise Rawlsian liberalism to enable it to adequately champion the cause of the poor.I provide an alternative definition of poverty and apply Mill's analysis of the relation between justice and utility to Rawls' theory of justice.

KEYWORDS: Justice, poverty, Rawls, liberalism, Mill.

John Rawls judged that the strength of his conception of justice as fairness lies in the priority he assigns to liberty and in the requirement that "all inequalities be justified to the least advantaged" (Rawls 1971, p.250). If this requirement indeed has the dominating role that Rawls judges it to have in his theory of justice, then Rawls would no doubt be a champion of the poor. If one adds that in his view, the requirements of his theory of justice could also be fulfilled by a "liberal socialist regime," then it becomes clear what priority Rawls attaches to ridding society of inequalities and thus improving the position of the poor (Rawls 1971, p.280).

In this essay I argue that Rawls has strong moral intuitions about the eradication of poverty that leads him to champion the cause of the poor in his theory of justice. However, the conceptual framework and intellectual resources that he uses to articulate these intuitions are not fully adequate to give poor people the full protection they need. His strong moral intuitions against poverty cannot be accommodated neatly, simply, and coherently in his liberal theoretical framework as it stands. That, at least, is what I would want to argue for. As a result I want to refashion his theory so that it can properly account for all the fundamental interests of poor people.

I focus on a weakness in Rawls's theory, i.e. the way he deals with the idea of a social minimum. Although the idea of a social minimum can protect the interests of poor people properly, Rawls cannot neatly and coherently accommodate this idea in his theory of justice. I show how John Stuart Mill successfully argues for the inclusion of something akin to the social minimum as a fundamental part of any liberal theory of justice. Through incorporating Mill's emphasis, I then reformulate the first principle of Rawls's theory of justice to include concerns about a social minimum in a way that is consistent with the deep underlying value of respect in Rawls's own theory of justice.

In the first few sections of the article I demonstrate to what a significant degree Rawls's theory of justice deals appropriately with the deepest concerns of poor people by means of parts of his theory like his ideas on the function of justice in a society, his focus on the basic structure, the value of respect and self-respect, the original position, social primary goods, and the difference principle. I offer reasons in support of my claim that Rawls shows strong moral intuitions about the eradication of poverty that he converts into normative elements of his theory of justice. I present these reasons from the perspective of poor people applying Rawls's theory of justice to their position. I interrogate, as it were, the core elements of his theory from the angle of requirements poor people would set for a theory of justice able to protect and enhance 
their legitimate interest to have their poverty fully eradicated. Note that this interrogation takes place from a vantage point informed by the latest research on poverty done in the social sciences.

Next I show that Rawls's theory of justice cannot in the end fully and completely articulate all necessary elements to deal effectively with the core issues of poor people. I argue that his theoretical framework is inadequate, as his moral intuitions about the need to eradicate poverty do not fit seamlessly into his liberal theory of justice. His theory starts to struggle when he distinguishes between liberty and the worth of liberty, but really shows a significant flaw in the way he deals with the idea of a social minimum. I explain his unsatisfactory presentation of the idea of a social minimum and his lack of appropriate response to critiques of it as an important theoretical flaw in his theory that he deliberately allows so as to retain in tact his liberal emphasis on the primacy of political rights. Also, I point out that his identification of poor people as the least well-off, or least advantaged, members of society is not an adequate delineation of those who are poor in society, as his definition rests on inappropriate grounds.

I then proceed to show a new way of properly accommodating the idea of a social minimum that goes beyond existing critiques by dealing with the social minimum in a way that is consistent with some of the most fundamental aspects of his theory, i.e. those parts that emphasise the important link between justice and respect. The implication of this new proposal is that a consistent Rawlsian theory of justice ought to give equal priority to both securing individual political liberties and protecting fundamental security for everyone. I present an alternative first principle of justice to revise Rawlsian liberalism to enable it to adequately champion the cause of the poor. I do this in conjunction with providing an alternative definition to identify poor people and by appropriating John Stuart Mill's analysis of the significance of justice for security and the satisfaction of basic needs. I then present a reformulation of Rawls's first principle of justice in terms of the core value of respect for every citizen. Throughout the article the focus is on retrieving the significance Rawls assigns to the function of a conception of justice to ensure respect for every citizen, showing a new way in which this emphasis can guide the struggle to eradicate poverty.

\section{Rawls: A champion of the poor}

Several aspects of Rawls's theory of justice have deep significance for the interests and well-being of poor people. In this section I argue that his ideas on what justice is, on the importance of the basic structure as subject of justice, and his emphasis on self-respect and equality make him a champion of the poor.

The best way to present Rawls's views on justice from the perspective of the poor is to systematize them by means of one of Rawls's own expressions, i.e., that justice means social co-operation among equals for mutual advantage (Rawls 1971, p.14). For desperately poor people, who are often neglected and pushed to the margins of society, this phrase in itself has powerful implications. To be regarded as equals by the rich and the powerful, worth enough that the latter co-operate willingly in a way that is to the advantage of both parties, will in itself enhance the self-respect and socio-economic position of poor people.

How do these ideas promote the interests of poor people? An important part of having respect for one's fellow citizens in a democracy is to acknowledge that public decisions are to be made collectively (see Lötter 2008). If fellow citizens are treated with respect, they will both have opportunities to influence public decisions and such decisions will be justified to them on grounds they can accept (see Gutmann and Thompson 1996). If, however, powerful citizens are allowed to manipulate or steam-roller public decisions at the expense of poor citizens and on the basis of reasons poor citizens reject, they are showing them disrespect. 
The ethical norm for democratic deliberators is simply put by Iris Young, "Deliberators should appeal to justice and frame the reasons for their proposals in terms they claim that others ought to accept" (Young 2003, p.103). If the rich and powerful dominate public dialogue through the use of their impressive resources to protect and advance their interests at the cost of poor people and thus silence the weak and vulnerable in the process, then core democratic values fail to protect the dignity and interests of those who need protection most (Young 2003, p.103). Thus, the Rawlsian idea of justice as social co-operation among equals for mutual advantage can sharply increase the levels of participation of poor people in political processes of decision making about the fundamental matters that determine their life conditions. In Nancy Fraser's view (2009, p. 16) they would have been given justice in its "most general meaning," i.e. "parity of participation," which means that all citizens can "participate as peers in social life."

Let us examine in more depth and detail what the Rawlsian expression that justice implies "social cooperation among equals for mutual advantage" means for the poor. When Rawls refers to social cooperation, he has a specific conception of society in mind. A just society will have a system of rules aimed at efficient and mutually advantageous social co-operation that produces greater benefits and advantages for everyone involved (see Rawls 1971, pp. 4, 6, 15). How does a just society improve the well-being of every citizen? For poor people Rawls's way of determining a fair distribution will be comforting, as not the superior economic, social or military powers of the rich and powerful will determine a just distribution, but a common point of view where their perspectives are included (Rawls 1971, p.5). Conflicts of interest can be settled by appealing to mutually agreed to principles of justice, providing a fair, impartial, and objective viewpoint from which to resolve disputes.

Why is this aspect of his theory so important to poor people? A drastically unequal distribution of economic capacities easily manifests itself in the political arena where poor people cannot compete on equal terms with non-poor people. Alcock $(1993$, p.212) refers to the "debilitating consequences of poverty and deprivation for participation in political activity." Poor people can be prevented from effective participation in public dialogue for reasons like not having enough time available, not having appropriately developed capacities and sufficient resources for engaging in democratic deliberation, and not having clout enough to help set public agendas by offering possible alternatives (Bohman 1996, pp.15, 18, 36, 65, 66, 108, 110; Dryzek 2000, pp.86, 172; Young 2003, pp.110, 113).

The consequence is often that material inequality is turned into political inequality, thereby undermining equal participation through effective voice for poor people. Socio-economic inequalities can thus have strong impacts on democratic decision making. Citizens bolstered by their wealth do not feel much need to shift their positions in public dialogue as their opponents are too weak to make them reconsider alternatives (Bohman 1996, p.65). As a result democratic decision-making suffers, as significant sections of the political community do not have effective input to determine agendas, much less, outcomes of public dialogue. They are virtually sidelined or even excluded from public dialogue, but made politically subject to the outcome of decisions they were too weak to influence (Bohman 1996, pp.125, 126).

The result of unequal political participation is that poor people's "needs are often overlooked, neglected, or very insufficiently provided for" (Gewirth 1984, p.564). They become unable to influence political decisions to favour their interests and views. The democratic assumption articulated by Rawls in his theory of justice, i.e. that to give people respect means they ought to participate as free and equal citizens with roughly equal voice and similar opportunities to influence the outcome of decisions that will influence their lives, is violated in this way. The legitimacy of democratic decisions is thus suspect, as they were not taken through "fair and inclusive processes of communication" (Fraser 2009, p.155). Furthermore, poor people thus do not experience efficacious political participation, through which they would have been "capable of influencing 
the use of public power and of holding public officials accountable" (Fraser 2009, p.155).

\section{The Basic Structure and Poverty}

Another aspect of Rawls's ideas on justice with important consequences for poor people is his ideas about the basic structure of society as the appropriate subject of a theory of justice. To implement his theory of justice, Rawls often uses simplifying devices. Rawls uses the notion of the basic structure to explain his understanding of the core aspects of society that are subject to justice. He defines the basic structure as consisting of the major institutions in society (Rawls 1971, p.7). Rawls sees a major division in society's basic structure consisting of two distinct parts, with the political institutions on the one hand and the economic and social institutions on the other (Rawls 1971, pp.61, 63). ${ }^{1}$

Rawls is explicit about his choice of the basic structure as the primary object to which principles of justice ought to apply - poor people would agree and even applaud his reasons. Apart from defining a citizen's rights and duties, the basic structure in most societies contains "especially deep inequalities" that strongly affect any person's chances in life. These effects, Rawls, says, are "so profound and present from the start" (Rawls 1971, p.7). They determine "what kind of person they can expect to be" and influence the prospects of "how well they can hope to do" in life (Rawls 1971, p.7). The basic structure houses different social positions into which individual citizens are born (Rawls 1971, p.7). This position "materially affects" the possibilities available to anyone in life (Rawls 1971, p.13). Desperately poor people will affirm this.

Let us examine in more detail how poverty made possible by the basic structure of society affects the possibilities and options available to poor people that determine and shape their life chances. Any person's development is closely linked to economic capacities and publicly provided opportunities that make education and training possible. The things that a specific person can do or not do - their capabilities depend on "specific, effectively resourced capacities which they can deploy in actual circumstances" (O’Neill 2001, p.189). ${ }^{2}$ To what extent does the lack of economic resources not diminish poor people's capabilities to do things they need to do for themselves?

Let us first look at poverty's effect on children. Even the quality of parental upbringing at least partially presupposes adequate economic resources. In most societies people have strong moral views on the need for children to have enough food and a proper education. If growing poor children with developing bodies do not have adequate nutritious food, surely their physical development and growth will be stunted, as is true of poor people generally.

Poor people furthermore often find it difficult to acquire resources to provide schooling to their children, if adequate public provision is unavailable, inadequate, or costly. The World Bank (2001, p.27) states that in some poor countries, "most children from the poorest households have no schooling at all." In some poor societies children are required to earn money by working like adults and this happens most often "at the expense of schooling" (World Bank 1990, p.31). Poor young people acknowledge the value of education and its significance in finding employment. They therefore express "despair over the obstacles to obtaining education, especially secondary school fees” (Narayan \& Petesch, p.2002, 65).

\footnotetext{
${ }^{1}$ G.A. Cohen (2008: 126) has a clear understanding of what the basic structure is about, as his concern is with the "pattern of benefits and burdens on society." He sees the basic structure as "neither a structure in which choice occurs nor a set of choices, but the upshot of structure and choices alike."

2 Amartya Sen (1990: 114) refers to a person's capability to "achieve various alternative combinations of functionings, or doings and beings." For Sen this means their "actual freedom," that he describes as "the freedoms they actually enjoy to choose between different ways of living that they can have reason to value." Note the crisp way that Cohen (1989: 944) distinguishes between people's possession of resources and the use they make of it: "What goods do to or for people is not identical with what people are able to do with them..."
} 
Like children adults also need to sharpen their skills and increase their knowledge. To survive in contemporary fast-changing societies, most workers need to engage in continuous education, upgrade their skills, and acquire flexibility to adapt to new work conditions. Failure to do so often results in unemployment. Lack of economic capacities makes it impossible for poor people to personally develop their employability. Often the low-level jobs of some poor people do not include any form of education or training. Poor citizens furthermore do not have equal and fair opportunities to be appointed to jobs or they do not have or ever had the means to gain "the skills needed for performance of these positions" (Little 2003, p.44). Thus, poor people can affirm the Rawlsian emphasis on the deep impact of the basic structure of society on their lives and agree why making that structure more just will significantly improve the quality of their lives.

\section{Rawlsian Equality and Poor People}

Thus far we have seen that John Rawls's theory of justice aims to facilitate social co-operation for mutual benefit of every member of society on condition that every citizen participates as an equal. From the perspective of poor people this view will bring them enormous benefit. Let us now investigate how Rawlsian equality has three further focus points for poor people. One is self-respect and the value Rawls assigns to it. Rawls places a major emphasis on the value of respect and self-respect in the lives of citizens. The other two are the deontological nature of Rawls's theory and the reasons for his explicit rejection of utilitarianism, as well as the values underlying Rawls's construction of the original position and the veil of ignorance.

For Rawls the loss of self-respect is so bad that the social conditions that undermine self-respect ought to be avoided "almost at any cost" (Rawls 1971, p.440). Why does he judge loss of self-respect such a disaster? His description of the psychological condition of loss of self-respect is akin to depression, as well as some of the negative feelings that poor people often experience. People may either feel that nothing is worth doing, or they might have lost the motivation and will to do worthwhile things (Rawls 1971, p.440). With loss of self-respect people feel their desires and activities have become "empty and vain" and they thus sink into "apathy and cynicism" (Rawls 1971, p.440). One of the sources of loss of self-respect is that some citizens must unfairly accept a "lesser prospect of life for the sake of others" (Rawls 1971, p.181), as often expected from, or enforced upon, poor people.

How does Rawls define self-respect? When persons have self-respect, they judge their own lives as valuable and think that their conceptions of the good, their life plans, are worth carrying out (Rawls 1971, p.440). They furthermore have self-confidence that they are able to accomplish the goals they have set themselves (Rawls 1971, pp.178,440). Self-respect, so defined, is not an individual matter and responsibility only. Rawls claims that every human being is owed respect as a moral person, irrespective of the person's social position. This respect must be publicly expressed through a conception of justice.

Respect owed to each citizen must be affirmed in public institutions and be embodied in the constitution of society. What does this mean? Equal treatment according to the first principle provides the basis for selfrespect in a just society. This, however, is not yet enough. The basic structure of society must show a commitment that every citizen's good is included in a system of social co-operation aimed at "reciprocal advantage" or "mutual benefit" (Rawls 1971, p.179). These two aspects combined, though, are not yet enough either. To ensure respect for other citizens Rawls wants a further commitment, i.e., that those citizens who have been fortunate in terms of the natural talents they were born with, or had the good luck of growing up in favourable social circumstances, should not exploit these contingencies which they did not 
deserve at the cost of those less fortunate (Rawls 1971, p.179). Rather, they must be prepared to use their good fortune for the benefit of those people who are worst-off in society.

Let us unpack the link between poverty and the loss of self-respect in more detail, as it forms a crucial part of my argument. Merely to suffer from poverty constitutes one serious blow to a person's dignity, as it signifies a lifestyle below that judged appropriate for human beings in a particular society. Furthermore, if one's fellow citizens ignore your condition and allow you to continue suffering from poverty it strikes another blow to poor persons' dignity, as they are excluded from care apposite to beings of their kind. The truth of these claims is shown in the fact that poor people so often resist being described as "poor". Why would they do that?

Some poor people resist being called poor, because poverty refers to a condition where a lack of economic capacities causes its human victims to live lives where they cannot fully participate in the range of activities expressive of their nature as human beings. Sometimes poor people may not even be able to maintain their physical health (see Halleröd 2000, p.167). To describe someone as poor thus indicates when a person has fallen below the standard of life thought appropriate for a human being in a specific society. Little (2003, p.23) correctly argues that "among the diminishments imposed by poverty are enduring assaults to human dignity over the whole of a human life." People who lose their human dignity through poverty also often lose respect from others and self-respect as well.

Poverty as condition that strips citizens of their human dignity is no natural disaster in which humans play no role. Rather, poverty results from the choices humans make about the values and organizational structures of their society and from the social forces they allow space to operate to produce unequal distributions of income, wealth, and opportunities. The levels of poverty and riches in society are the collective product and responsibility of its citizens. Poverty and its negative consequences for the dignity of fellow citizens are thus the result either of what democrats do to their fellow citizens, or what they allow to happen to them.

We can thus reasonably assume that poverty results from the choices humans make about the distribution of income, wealth and opportunities in their society and from the social forces they allow space to operate to produce unequal distributions. If this is true, we can say that the levels of poverty and riches in society are the collective responsibility of its citizens. Whilst the loss of dignity associated with the condition of poverty can impact hugely on the self-respect of poor people, the fact that non-poor people so often ignore the plight of the poor adds insult to this injury. Can that be respectful treatment of fellow citizens?

If poverty is indeed a condition that results from collective choices made by fellow citizens, then it is a loss of self-respect caused or allowed by fellow citizens and thus also something that can be rectified. Poverty is thus a remediable condition that continues to exist by the grace of the political decisions of citizens who allow it to be. Whilst poverty reflects a condition in which human beings live lives below those their fellow citizens think appropriate for humans, it also shows that non-poor citizens do not care enough about victims of poverty to change the social order to prevent, ameliorate, or eradicate a condition that degrades fellow citizens. This attitude can only be described as deeply disrespectful.

If some humans are forced through a lack of economic capacities to live a life judged by their peers as below the standards set for humans in their society, such humans experience their human dignity violated. Ruth Lister $(2004$, p.100) states that for many poor people it is "the lack of respect and loss of dignity that result from 'living in contempt of your fellow citizens' that can make poverty so difficult to bear." If, in addition, their fellow citizens do not care about the degrading condition they face, poor people suffer the humiliation 
of being valued not worthy to be cared for. They are not regarded as human beings who ought to be treated with a certain minimum level of respect for their rights and concern for their well-being. In this case they experience their human dignity denied. They experience disrespect from their fellow citizens. This lack of care shown by fellow citizens adds another blow to their dignity, as they are not shown the consideration proper to humans in similar degrading circumstances.

The idea of a society embodying respect for each citizen in its fundamental ideas of justice links to the strong deontological nature of Rawls's theory. He explicitly rejects any kind of utilitarian justification of inequalities. In his words, "sacrifices imposed" on some citizens for the sake of a "larger sum of advantages" enjoyed by many (Rawls 1971, pp.4,14), or to "acquiesce in enduring loss" so as to bring about a "greater net balance of satisfaction" are both unacceptable (Rawls 1971, p.14). Why does Rawls say so? He believes that citizens who are one another's equals would never agree to any principle that would require them to make such sacrifices or acquiesce in such losses (Rawls 1971, p.14). Significant to note is that Rawls gives poor people a choice - through the original position - what social arrangements they would accept from a basis of equality. This choice - although as theoretical mechanism - restores poor people's self-respect, as poor people throughout the world are mostly coerced into acquiescence of the desperate circumstances they find themselves in. They are acknowledged and respected as human beings who deserve treatment on a par with every one else and their well-being is taken into consideration as much as everyone else's.

\section{The Original Position, the Veil of Ignorance, and Poverty}

The choice Rawls gives to everyone to consent to the justice of their society is detailed in his theoretical constructs of the original position and the veil of ignorance. The original position makes possible an imaginary choice by citizens as moral equals about principles of justice. The function of the original position is to vividly display the nature and reasoning for choices about justice when certain kinds of information are excluded (Rawls 1971, pp.18, 19). These kinds of information are things Rawls judges to be arbitrary from a moral point of view. The veil of ignorance functions to take away those kinds of information. With the veil, the parties to the original position enter symmetrical relations to one another and they are fairly situated as free and equal human beings (Rawls 1971, p.19). They thus cannot tailor principles to suit their own circumstances, whether they have been advantaged or disadvantaged by natural fortune or social circumstance (Rawls 1971, pp.12, 136). They are denied any opportunity of advancing their own cause through proposing and supporting principles benefiting themselves at the cost of others.

The theoretical device of the original position accomplishes an important ethical goal. The veil of ignorance equalizes the parties to such an extent that they cannot distinguish themselves from their fellow participants. They must decide on principles of justice realizing that they could be any person in any social or economic position in society. For this reason, Rawls can say that the parties are "forced to choose for everyone" (Rawls 1971, p.140). Through Rawls's theoretical construction he forces any participant - his readers included - to ask themselves how they would judge the justice of the society if they were the most advantaged or least advantaged persons in a particular society. For this reason he can legitimately claim that he forces each person "to take the good of others into account" (Rawls 1971, p.148).

Rich citizens must imagine themselves desperately poor without social assistance, for example, and poor citizens must imagine themselves enormously wealthy, but severely taxed. By choosing principles of justice so fair to each and every position in society that you would be satisfied even with whatever position your biggest enemy assigns you, accomplishes Rawls's goal of designing a theory of justice as fairness. Through the idea of the original position people who are marginalized and ignored are now given the comfort that the 
more fortunate and advantaged members of society must actively imagine how the lives of the least well-off citizens must be and take that into account in their decision making. They are thus fully respected as human beings in this way of making decisions about the justice of their society.

\section{Social Primary Goods and the Difference Principle}

Thus far we have looked at how Rawls understands social co-operation that takes place among equals. Rawls is explicit that this social co-operation among equals is for mutual advantage. The strength of Rawls's conception of justice to work positively for poor people really shows in the idea of mutual advantage. How strong this mutuality is, is clear from his restriction on the most advantaged members of society, i.e. that they should not have "a veto over the benefits available for the least favored" (Rawls 1971, p.80). To understand the full force of this part of his theory, I will first look at his idea of social primary goods, next at the difference principle, then at his priority for the concept of right over the good, and lastly at the link of the difference principle with his distinction between liberty and the worth of liberty.

Social primary goods are goods that a society can control and distribute. All rational people want these goods to support and execute their plans of life (Rawls 1971, pp.62,260). Rawls sets up a benchmark for equality (Rawls 1971, p.62). Imagine, Rawls says, an initial distribution of primary goods where everyone gets equal shares. Any inequalities of wealth or power deviating from the initial equal distribution are only justified if they would make everyone better off. This hypothetical distribution serves to illustrate Rawls's general conception of justice, the one that eventually develops into the special conception where the two principles of justice are arranged in serial order.

Rawls's difference principle - his second principle of justice in his special conception - deals with the social and economic benefits and advantages resulting from social co-operation (see Rawls 1971, pp.15, 43, 75, 83, 100). ${ }^{3}$ Its basic meaning is that every citizen must have the right to fair equality of opportunity and all inequalities must improve the lives of the least advantaged citizens and be justified to them. Behind the principle of fair equality of opportunity lies the idea that citizens with the same talent, ability, skill, and the willingness to use them should have similar life chances and the same prospect of being successful in life, regardless of the social circumstances they were born in (Rawls 1971, p.73). Behind the principle that all inequalities must be to the benefit of society's least advantaged members lies the idea that undeserved inequalities resulting from natural fortune and social position call for redress (Rawls 1971, p.100).

Alternatively put, those more fortunate can only benefit from the use of their assets in a way that provides compensating advantages to those who have lost out. Note that the principles of justice must be implemented in serial order, as simply described by Schaller (1999, p.368): "once the requirements of the First Principle of Justice have been satisfied, and once fair equality of opportunity exists, then the Difference Principle comes into play."

Rawls justifies his difference principle to both the most and the least advantaged citizens. To the most advantaged citizens his justification is that everyone's well-being depends on social co-operation (Rawls 1971, p.103). The most advantaged citizens must get the willing co-operation of the least advantaged citizens and therefore the terms of co-operation must be fair and reasonable (Rawls 1971, pp.15, 103). To exploit the least advantaged through making them offers they cannot refuse as a result of their lack of skills, talent, ability, or their unemployment, is unacceptable, disrespectful conduct towards fellow citizens in a

\footnotetext{
${ }^{3}$ The debate about the exact link and alignment between the role of the difference principle to shape "institutional design" and also "govern personal conduct" (Pogge 2000: 154) does not have any direct impact on the issue being discussed here. The outcome of the debate whether the difference principle "which condemns inequalities that contradict the interests of the worst off, applies not only to the actions of the state but also to the choices of individuals that are beyond the reach of the state" (Cohen 2008:8) will not significantly change the need for some kind of theoretical adaptation of Rawls's theory of justice that I argue for. See also Pogge (2000), Cohen (2008), and Murphy (1999).
} 
Rawlsian society consisting of people with equal dignity and moral worth.

These Rawlsian ideas put to shame the way many rich and powerful people treat poor people throughout the world. As a result of their observations in many countries of the world, poverty researchers question the wisdom of allowing economic and political institutions, policies, and practices that produce outcomes where millions of people cannot satisfy even their most basic needs to stay alive, whilst others have such quantities of resources to satisfy even their most frivolous wishes. Questioning these outcomes becomes a lot more serious when one notes that scientists have solid empirical evidence that the vast riches of some economically powerful individuals and groups rest on their exploitation of those who are economically and politically much weaker. This implies that the institutions, laws, rules, conventions, and practices operative in a society allow some to derive unfair benefits from the toil and labour of others.

For the least advantaged members of society the difference principle implies that they as the less fortunate should not support policies to stifle or minimize the talents of other citizens. Rather, they should view the greater talents, skills, and abilities of the more advantaged citizens as social assets to be used for the benefit of everyone involved. Thus, they must grant the talented incentives to deploy their superior skills and knowledge optimally for improving the lives of everyone in society (Rawls 1971, p.107).

Could Rawls convince the rich, powerful and talented to accept this difference principle? He seems to rely on two other factors, besides the one mentioned above, to help convince the more advantaged to benefit from their greater fortune on terms that improve the lot of those who have lost out. One factor is to rely on fraternity (solidarity), which he defines as the attitude that a person will only make use of greater advantages if they simultaneously benefit the position of those less fortunate (Rawls 1971, p.105). He makes a strong assumption that this kind of fellow feeling would exist. The other factor is the way he believes principles of justice ought not to take just any desires, aspirations, inclinations and satisfactions of citizens as givens, but should restrict and restrain them to what he calls reasonable conceptions of the good, limited by what justice requires (Rawls 1971, p.31). This is one aspect of what he means when he gives priority to the concept of the right over the concept of the good (Rawls 1971, p.31). Taylor (2003, p. 257) articulates what Rawls thinks it means for a citizen to be reasonable, i.e. "the ability to limit the pursuit of one's conception of the good out of a respect for the rights and interests of other people and out of a desire to cooperate with them on fair terms." Again we can see how the Rawlsian theory of justice champions the cause of the poor. Rich people ought to be willing to limit their preference satisfaction sufficiently for the sake of showing respect to poor people to enable the latter to have adequate resources to live lives defined by their society as worthy of human beings. However, the way Rawls constructed his theory makes it difficult to stay with this focus on championing the cause of the poor consistently.

\section{The Worth of Liberty}

The two final aspects of Rawls's theory that makes it favourable to the interests of the poor are his distinction between liberty and the worth of liberty and his ideas on a social minimum. Although these two aspects contain valuable moral sentiments supporting the interests of the poor, they start to unravel the flaw inherent in Rawls's theoretical framework that make him flounder as a consistent champion of poor people's interests and well-being.

In his discussion of liberty, Rawls refuses to identify poverty as a condition that constrains citizens from doing something or not (Rawls 1971, p.202). He prefers to name something a constraint when some other person interferes with a particular citizen's liberty. Thus, for Rawls poverty and ignorance affect the value and worth that liberties have for a citizen, but they should not be counted as constraints (Rawls 1971, p.204). 
It is hard to understand why not having transport, or not having enough energy to attend a political meeting as a result of lack of food, does not count as a constraint on my freedom of movement and political association. It is clear, though, why Rawls makes this choice (Rawls 1971, pp.204-205). He wants to align his first principle of justice, his definition of liberty, and the political institutions of society (one part of the basic structure) with one another. This alignment expresses his strong commitment to liberal political theory. He furthermore wants to align his second principle of justice with the worth of liberty and the social and economic institutions of society (the other part of the basic structure). This alignment might provide him with some theoretical elegance and coherence, but I will try to show that he eventually pays an unacceptable price.

The flaw in Rawls's thinking about poverty as a constraint on liberty becomes clearer when compared to Isaiah Berlin's closely similar, but still significantly different liberal position on this issue. Note how Berlin (1969, pp.122-123) argues that a person is politically free if no other human being, or group of human beings, interferes with, prevents or obstructs any action that the person can otherwise legitimately do. Berlin rules out incapacity to act as a result of non-human causes, such as disease, as a case of loss of political liberty. However, if poverty - and thus incapacity - results from other people's actions which have caused a person not to have sufficient money and resources, then Berlin judges it as a case of loss of political liberty.

Rawls's distinction between liberty and the worth of liberty seems to presuppose that poverty has either nonhuman causes or is the responsibility of the individual involved. Berlin's view opens up complicated issues about the nature and causes of a person's poverty. For Berlin poverty could be a loss of political liberty if others in any way contribute to, or are responsible for, an individual being poor. From recent poverty research done in the empirical sciences we know how often fellow human beings are the cause of some people's poverty. Thus, the way Rawls tries to deal with the idea that poverty merely causes a lesser worth of liberty, and is not a constraint on some imposed by others, seems seriously flawed.

\section{The Social Minimum and Poverty}

Whilst the ideas of liberty as distinct from the worth of liberty start unravelling a flaw in Rawls's theoretical framework, the idea of a social minimum reveals the flaw. In a more practical part of $A$ Theory of Justice where Rawls discusses the legitimate role of government in the market economy, he all of a sudden refers to a social minimum (Rawls 1971, p.275). Of the four government branches involved in the market economy, the transfer branch has the function to take needs into account and assign them proper weight (Rawls 1971, p.275). This branch must guarantee a social minimum. For me the link between a guaranteed social minimum and the contents of the two principles of justice is not evident.

How exactly does Rawls infer a guaranteed minimum from the two principles of justice? This inference is not clear. Or maybe the idea of a social minimum is just some kind of convenient assumption? The first principle that guarantees equal liberties is to be fulfilled fully and completely as serial ordering requires before the second principle comes into play (Rawls 1971, p.43). The principle of equal liberties does not require a social minimum. Remember, the worth of liberty is dealt with by the second principle. So it is possible that in a Rawlsian just society a person can have full equal liberties like any other citizen, but still be desperately poor. ${ }^{4}$

\footnotetext{
${ }^{4}$ In his defense of the priority of liberty, Taylor (2003: 263 - 264) discusses the need for a threshold of wealth needed before the priority of liberty can apply. He says that the priority of the first principle of justice "would be meaningless in a society that could not even establish the basic liberties themselves due to social and economic conditions." However, like Rawls, Taylor does not want to modify the two principles and the lexical priority Rawls assigned to their implementation. Like Rawls, he prefers to "simply stipulate" the implementation of the first principle "until all primary goods that are necessary for the advancement of our highest-order interest in rationality can be made available." A very convenient dismissal of a major issue of social justice, I think.
} 
I am not convinced that the difference principle provides explicit reasons for a social minimum either. ${ }^{5}$ The difference principle deals with the distribution of advantages that arise from social co-operation that should benefit those less fortunate. Exactly how much that benefit must be and whether it will be enough to lift people from their poverty is not clarified. ${ }^{6}$ The difference principle gives incentives to the talented and support to the least advantaged. Precisely how its central concepts must be interpreted to permanently eradicate poverty is unclear. Note how Schaller (1998, p. 371) interprets the difference principle as suggesting "what is to be maximized are the lifetime expectations of the ...least advantaged representative person." That does not necessarily imply that all poor persons will be rescued from the ravages of poverty so that they can be classified as non-poor. Furthermore, the application of the difference principle is difficult to judge, far more so than the application of the principle of equal liberty, by Rawls's own admission (Rawls 1971, pp.97-98, 199). The difference principle is not formulated in terms of rights which individuals can claim, so it is not clear that every individual is entitled to a social minimum if based on the difference principle.

Perhaps Rawls cleared up this issue in his later publications? Unfortunately not. In Political Liberalism (1993, p.6) Rawls says that all the elements relating to his two principles of justice "are still in place, as they are in Theory," and though he has revised some ideas contained in A Theory of Justice, "none of them affect this feature of it" (Rawls 1993, p.6). He acknowledges the problem of the social minimum in response to criticism expressed by Rodney Peffer (1989, pp.381 - 385). The upshot of Peffer's criticism is his challenge that Rawls ought to have a principle to enable "a minimum floor of well-being below which persons are not allowed to fall, and this principle must take precedence over any other principle of social justice" (1989, p.404).

One must quote Rawls in full to appreciate the concession he makes to this kind of critique. He acknowledges that his first principle of justice,

“may easily be preceded by a lexically prior principle requiring that citizens' basic needs be met, at least insofar as their being met is necessary for citizens to understand and be able fruitfully to exercise those rights and liberties. Certainly any such principle must be assumed in applying the first principle. But I do not pursue these and other matters here." (Rawls 1993, pp.7-8, my emphasis).

Why on earth would Rawls fail to pursue such a serious matter? One that makes his distinction between liberty and the worth of liberty almost obsolete? A matter that might imply - by his own acknowledgement a lexically prior principle to the first principle of equal liberties? Schaller (1998, p. 376) refers to the social minimum as a “necessary component of Rawls's theory of justice." In Political Liberalism Rawls calls social primary goods all-purpose means $(1993, \mathrm{p} .76)$, but still does not modify his theory to accommodate a "lexically prior principle." However, he does not address the place and justification of the social minimum in his revised theory of justice, but rather focuses on the issue of moral pluralism instead.

If Rawls acknowledges that his two principles of justice "may easily be preceded by a lexically prior principle requiring that citizens' basic needs be met" and he agrees that "[c]ertainly any such principle must be assumed in applying the first principle," then one can easily imagine that Rawlsian negotiators in the original position could have followed a different route than the one Rawls imagines. They could have argued as follows. They might have insisted that if principles of justice are indeed necessary to adjudicate

\footnotetext{
${ }^{5}$ In my discussion I am not focussing on all possible aspects of critique against the difference principle. As Arneson (1989: 700) says, the "criticisms are legion." I am only focussing on its inability to definitively protect any human being against the ravages of poverty.

${ }^{6}$ DiQuattro (1983: 62) argues that the difference principle "does tolerate - indeed requires - limited differentials, and even after state activity takes its toll in narrowing initial class inequalities, there may remain disparities of life prospects among members of the different classes sufficient to raise doubts about the justice of such an arrangement."
} 
the fair distribution of benefits and burdens that result from social co-operation, as Rawls argues, then the equal distribution of sufficient primary goods by means of a normative principle ${ }^{7}$ to protect all citizens from the ravages caused by poverty seems paramount. To safeguard respect for each citizen by providing full protection against poverty seems consistent with Rawls's own emphasis on the link between justice and respect. These primary goods must include enough resources for adequate food, clothing, shelter, basic medical care, and adequate protection from crime. ${ }^{8}$ From another perspective this choice would again make sense, if the function of the original position is read as a device for rational agents "desirous of safeguarding their life-prospects" (Arneson 1999, p. 100).

I would like to contend that to have sufficient resources to enable every citizen to live a human life with dignity, worthy of basic respect from fellow citizens, is the fundamental protection Rawlsian negotiators would insist on in the original position. They would want to be protected from a condition like poverty by having guaranteed access to basic primary goods or resources beyond a collectively determined threshold (see Pogge's suggestion in 2000, p. 163). If the Rawlsian people in the original position would want to ensure all possible social positions in their just society are such that even their worst enemies could assign them any place and they would still be well-off enough, then surely they would also choose for adequate protection against the negative effects poverty causes? One can easily imagine that this matter could be so important that they would insist on a safeguard embodied in a fundamental principle of justice.

If they choose such a principle, the matter of the distinction between liberty and the worth of liberty would become much less important. All citizens with sufficient resources to fulfil basic needs will be able to use their liberty effectively. Inequalities in the distribution of wealth and income might still matter, but for other reasons.

In his last book, Justice as Fairness (2001), Rawls considers whether the difference principle should be included amongst what he calls "constitutional essentials." He rejects such an idea as the fulfilment of the difference principle "is extremely difficult to settle with any exactness" (2001, p.162). However, Rawls now opts to include the idea of a social minimum amongst the constitutional essentials, in response to an earlier challenge about this issue directed at him by Jeremy Waldron (see Waldron 1986). Still, no mention of the social minimum is made in his revised versions of his principles of justice, as their revisions in his last book "are merely stylistic" (2001,pp.42 - 45). Thus, although he acknowledges the fundamental importance of the social minimum, he is unwilling to modify his two principles of justice.

Rawls's flaw is thus to ignore the value and importance of the social minimum in the formulation of his principles of justice throughout all his writings by not integrating it coherently with his strong emphasis on the role of justice to secure respect for every citizen, or to embody it in a principle of justice. How can this flaw of Rawls be satisfactorily explained?

The flaw of the social minimum without adequate theoretical space and justification comes about through Rawls's strong commitment to traditional liberal political theory where individual rights to liberty have priority. In addition, he applies his theory to the basic structure of society, split in two parts to correspond to his two principles, and thus also reflecting the priority of liberty. Rawls's moral sentiments tell him that a

\footnotetext{
${ }^{7}$ Cohen defines a normative principle as "a general directive that tells agents what (they ought, or ought not) to do" (Cohen 2008: 229).

8 The idea is that a basic equal distribution of primary social goods is too important to leave to the status of some kind of precondition to be fulfilled before the implementation of the priority of liberty. This matter should rather be addressed by means of a principle of justice, or, as in the case of Henry Shue and Alan Gilbert, by means of the idea of basic rights. For Gilbert (1898: 235) basic rights protect "the preconditions for human agency" that includes "not only life, moral and physical security, but subsistence, adequate shelter and health care, and a decent environment." The fact that Rawls ignores the fundamental importance of the role of the environment as a life giving and life enhancing factor in human life that we ought to consider in the original position will not be discussed in this essay.
} 
social minimum is of crucial importance for the physical survival of individual persons, but his theoretical commitments do not allow him to create the necessary space and justification for a social minimum meaningfully theoretically integrated. Instead, the idea of a social minimum appears as a theoretical add-on, an element Rawls knows he must acknowledge, but something he does not know how to handle or where to take. Thus, the social minimum does not coherently fit into his theory. I will argue that due recognition to the fundamental role of respect in his theory of justice will satisfactorily address this matter.

\section{Rawls's Definition of Poverty}

An associated problem that jeopardizes the ability of Rawls's theory of justice to consistently champion the cause of the poor, is the way that Rawls defines who poor people are, those whom he identifies as the least advantaged members of society. His definition is a quantitative one, rather than a moral one in terms of the core concepts of his theory. Rawls defines two social positions from which he believes the application of his principles of justice must be done. The position of representative citizen does not concern us here as does his attempt to define various levels of well-being, which he finds much more difficult and arbitrary - and less satisfactory - to define (1971, p.94).

Rawls acknowledges that the most serious difficulty is "how to define the least fortunate group" (1971, p.98). He almost gives up on his attempts to accurately define the least well-off group in society when he says, "we are entitled at some point to plead practical considerations in formulating the difference principle. Sooner or later the capacity of philosophical or other arguments to make finer discriminations is bound to run out" (1971, p.94). The proposal Rawls offers to define the least advantaged people in society boils down to taking either the specific social position of the unskilled labourer as benchmark, or setting less than half of the median income as another possible benchmark. Rawls thinks that either of these definitions "will serve well enough" (1971, p.98), especially if they are "acceptable from their standpoint” (1971, p.99).

The problem with this definition is its inability to provide an accurate, precise demarcation between poor and non-poor people, as well as the basis of the definition that comes from quantitative measures concerning levels of available material resources. To merely use the bottom $20 \%$ or $40 \%$ or $50 \%$ implies that the categories of poor people will always be with us in similar percentages, though it is common knowledge that in some countries a much larger percentage of the population can be described as poor than in others. For these reasons the definition is inadequate, in addition to the fact that Rawls could not find a definition in terms of the central moral and political values of his theory. The advantage of the definition that I employ is that it defines poverty in terms of the impact it has on the respect shown to citizens by themselves and others.

\section{An Alternative Formulation: Using John Stuart Mill to Clear the Way}

In what follows, I show that an alternative formulation of Rawlsian principles of justice can accommodate the idea of a social minimum, but with an added justification that comes from the role of justice to give respect to each citizen. The argument will proceed as follows. I first discuss John Stuart Mill's ideas on the meaning and value of justice for individuals. These ideas provide both an understanding and a justification of the significance of a conception of justice that can accommodate the idea of a social minimum. Then I redefine what it means to be poor and finally I provide reformulated principles of justice and a defence thereof.

Rawls (2007, p. 267) believes that the contents of Mill's conception of justice is not only "very close" to his conception of justice as fairness, but is "close enough" that he regards the "substantive content" of the two 
theories as "roughly the same." For this reason a close look at both the contents of Mill's theory of justice and his justification thereof might prove instructive for my project to revise Rawls's first principle of justice. In addition it is important to note to what extent Mill as the great champion of liberty valued the significance of security and the fulfilment of basic needs as well. To respect individuals means to properly acknowledge the huge value they attach to personal security. Mill, the champion of liberalism, shows how liberty, security, and the adequate fulfilment of basic needs can coherently fit into a liberal conception of justice.

In Mill's discussion of the relation between justice and utility, he leaves no room for doubt that justice can clearly be distinguished from all other kinds of moral values. Mill refers to the "superior binding force" (Mill 2003,p.217) of justice which has "more absolute and imperative" requirements that do not only differ in degree from other moral values, but in kind (Mill 2003, p.235). Mill assigns extraordinary importance to the functions of considerations of justice within a human society, therefore he recognizes that the moral requirements of justice "stand higher in the scale of social utility" (Mill 2003, p.234) and thus considerations of justice evoke powerful, intense human emotions.

Why does Mill think that rules and principles of justice are not only the "chief part," but also the "most sacred and binding part of all morality" (Mill 2003, p.231)? For Mill justice secures the "very groundwork of our existence" (Mill 2003, p.227), and people's obedience to rules of justice "alone preserves peace among human beings" (Mill 2003, p.231). Considerations of justice have this value because this kind of moral rules and values are "vital to" and "concern the essentials of human well-being" (Mill 2003, p.231). For Mill human well-being is more than having political rights, thus he includes having enough food, clothing, shelter and physical security - all matters of great importance for poor people.

Mill thus sets up an argument to show that the enjoyment of everything else depends on lasting security, as proper security is the basis for everything else we meaningfully do. For this reason he refers to security as "the most indispensable of all necessaries" as it ensures that human beings can access and experience the "whole value of all and every good" (Mill 2003, p.226). Mill is clear that justice must enable human beings to enjoy security, "to everyone's feelings the most vital of all interests" (Mill 2003, p.226). To be safe in life and limb and healthy in body and mind are necessary prerequisites for making use of most other opportunities justice offers.

Mill's discussion of justice points to the immense value of security as prerequisite for having and making use of all other liberties and opportunities humans value in society. Note that he explicitly states that "physical nutriment" is even more important than security (Mill 2003,p.226). Thus, Mill sees justice as protecting the value and significance of the preconditions for free human action, such as nourishment and security. These preconditions enable human action by which an individual engages in freely chosen activities and utilises socially available opportunities. This role of justice is exactly what is required to protect all the fundamental interests of poor people.

Furthermore, Mill's appeal to social utility in the deeper sense of human emotions that respond to the suffering and pain caused by the well-known "positive evils of life" (Mill 2003, p.192) provides an alternative, complementary justification for ideas of justice besides hypothetical thought experiments and the intuitive ideas embodied in our tried and trusted political systems. This appeal can help us appreciate the deep suffering and emotional pain caused by poverty that we must prevent appropriately by means of our principles of justice.

Mill can also relate to the Rawlsian idea that we can justify a theory of justice with reference to the ideas and intuitions embedded in our democratic institutions. Part of our reasons for a particular conception of justice, Mill says, comes from how we have "been learning by experience the tendency of actions" over centuries and thus have "acquired positive beliefs as to the effects of some actions" on our human happiness and well-being (Mill 2003, p.200). Thus, humans throughout history learn through self-consciousness, selfobservation, and rational thinking what actions and circumstances generally cause suffering and distress and 
are thus to be avoided (Mill 2003, p.190). The results of these social learning processes are embodied in traditions, texts, and institutions passed from generation to generation.

Mill's way of providing reasons for specific requirements of justice related to security in a broader sense might not be so far removed from Rawlsian thinking as one might suspect at first glance. Scanlon (1975, pp.183 - 184) argues that one could justify restrictions on basic liberties for more reasons than just their negative impact on the scheme of basic liberties, as many readings of Rawls would suggest. Scanlon concludes $(1975, \mathrm{pp} .183,184)$ that on a close reading of Rawls, the exercise of some basic liberties can be curtailed if it will "lead to consequences generally agreed to be harmful for all," or when their exercise goes "against the enjoyment of other goods."

If one adopts Mill's way of looking at the role of justice to prevent the major evils of human life, ${ }^{9}$ there can be no doubt in anyone's mind that we must take very seriously the destruction, distress, dehumanization, and disrespect that poverty causes. If we have not been aware of these consequences in the past, then numerous poverty studies in the past three decades have made this kind of information available to everyone. We do know now what poverty does to people and how people, victims of poverty and observers alike, respond emotionally to the various kinds of suffering poverty inflicts on human beings. For this reason we have no justification anymore for not developing conceptions of justice to protect victims of poverty from its ravages.

Thus, if we accept Mill's emphasis on security as part of what justice requires and combine it with Rawls's emphasis on the impact of justice on respect for individuals, how can we develop a theory of justice that gives proper recognition to the deep emotions evoked by the conditions and consequences associated with poverty? To do so, we must first briefly define poverty and specify some of its consequences in short. Note how this definition of poverty tries to improve on Rawls's identification of the least well-off members of society that he based on percentiles of income distribution or a certain class of labourer. My definition of those who are poor has an explicit moral basis consonant with the core values of Rawlsian justice. Next I will modify the first principle of Rawls's special conception of justice to rectify its flaws so as to be able to fully respect the humanity of poor people by protecting all their interests, security especially.

\section{Dealing with Two Kinds of Poverty}

Social science researchers refer to two kinds of poverty, usually called absolute and relative poverty. I rather propose the use of the ideas intermediate poverty and abject poverty, as argued for elsewhere, as they express the intended distinction more accurately. Intermediate poverty falls in between abject poverty and not being poor at all. Abject poverty thus always includes the characteristics of intermediate poverty too.

Intermediate poverty refers to the loss of human dignity persons suffer as a result of their inability to engage in typically human activities defined as necessary for a normal, decent human life as specified by their society. The universal element in this definition is the loss of dignity as a result of not living a fully human life as defined by one's society, while the contextual elements are found in the nature and possibilities of human life as found in the society a person lives in.

Abject poverty is defined as the lack of economic capacities that endangers a person's health, as the person cannot acquire the economic means to sustain human life, such as food, shelter, clothing, and minimal

\footnotetext{
${ }^{9}$ Stuart Hampshire (1989: 90) argues that all moral judgements and arguments presuppose that the great evils experienced by human beings must be avoided. Although background to all moral theorising, Hampshire says the concept of justice in particular can only be fully understood when the "forces of destruction" that justice intends to avert, are taken into account (Hampshire 1989: 68). For this reason Hampshire thinks that justice, in one sense, is a negative virtue, as it aims to prevent negative and harmful acts and experiences. In agreement with Michael J. Sandel (1982: 30-35), Hampshire argues that justice comes into play to resolve conflict peacefully where friendship, kinship or shared communal values break down (Hampshire 1989: 55). Justice is thus necessary to human associations for preventing minor conflicts escalating into major disasters.
} 
medical care. Abject poverty includes the characteristics of intermediate poverty as well, thus the loss of human dignity features even more prominently with the added burdens of abject poverty. The universal elements in this definition can be seen in the fact that we can measure gradual deterioration of physical health in human beings in various ways, such as intake of nutritious foods, weight loss, stunted growth, susceptibility to disease, and so on. The contextual elements can be seen in the fact that what is available as food, clothing, shelter, and medical care differ from society to society. Similarly, individual variations are obvious, as people's nutritional and medical requirements especially are not the same. Nevertheless, the universal elements can be applied more or less accurately for measuring exactly when an individual in a specific society reaches the point that a lack of economic capacities leads to a deterioration of physical health.

Some of the well-known consequences of poverty of whatever kind, as established by social science researchers, are that poverty leads to disease and death, undermines the human dignity of its sufferers, leads to a waste of the human potential of its victims, have a negative impact on many human relationships, often leads to public humiliation for poor people, and creates more burdens and reduced quality of life for the poor. These consequences cause deeply felt emotions in both victims and observers that urge us to do something to alleviate or eradicate a condition that leads to so much suffering and misery.

One must note that three main factors drive the moral emotions about poverty. The suffering poverty causes, the disablement that leads to missed opportunities, and the loss of human dignity and respect that results lead many people to see poverty as a condition humans ought to tackle with vigour and commitment. If this is true, then the Rawlsian principles of justice can be modified as follows to address this unfortunate condition, by placing much more emphasis on the role of justice securing respect for every citizen.

\section{Reformulating the First Principle of Justice}

As Michelman (1975) points out, and as has been shown earlier in the essay, Rawls aims to secure respect (and self-respect) for individuals through the general thrust of his whole theory of justice. Especially the first principle of justice with its emphasis on equal liberties expresses such respect. Thus, one can imagine a reformulated first principle of justice that runs as follows, "Everyone has a right to equal respect that will protect their human dignity." Both the denial of individual liberty rights and being abandoned to suffer from poverty are conditions that deny human dignity and thus express disrespect for individuals. The significance of being enabled to have a "threshold level of self-respect" is argued for by Arneson (1999, p. 103), who claims that without it "one would be unable effectively to take advantage of the formal liberties and material resources" made available by a Rawlsian just society.

The reformulated first principle of justice can be split into two co-original parts to be implemented simultaneously, as they contribute similarly to equal respect for human dignity. The now familiar formulation of the Rawlsian first principle of justice that covers equal liberties I now regard as the first part of a reformulated first principle. As the second part of a revised first principle I propose the following. "Everyone has a right to a minimum social security that will enable them to live a decent human life as defined and respected by their society." Only through both these two guarantees, i.e. equal political rights and protection of our fundamental security, that includes food, shelter, clothing, medical care, and physical protection against harm from other humans, do we show one another minimal respect as human beings and fellow citizens.

How will this formulation affect the difference principle? As Waldron (1986) has argued, the idea of a social minimum might not go very far towards equalizing income and wealth, despite the protection it offers to the 
people below the poverty line. If the social minimum eradicates poverty completely, the difference principle with its bias towards working in the best interest of the least advantaged members of society will still be useful, but for different reasons. The justification for its tendency towards equality will now have to rely on justifications like the value of reducing huge disparities between the income and power of rich and poor in society.

\section{Conclusion}

I proposed a revision of Rawlsian liberalism to modify the emphasis on the idea that political liberties should enjoy lexical priority and that the idea of a social minimum can be hidden or disposed of as not one of the prime priorities of a theory of justice.

My alternative might usefully be called a fusion of Rawlsian and Millean liberalism, but can also be termed social democratic consequentialist liberalism. The 'social' aspect refers to the value the social minimum has for many poor people's lives and 'democratic' to the lessons learnt over decades how effective such institutions deal with containing political power within ethical bounds. 'Consequentialist' points to the justificatory process of taking seriously the well-known effects of a major disabling condition like poverty. 'Liberalism' still shows us the value of human liberty to construct meaningful lives for ourselves within the constraints and possibilities of our democratic institutions once the preconditions for a decent human life that is respected by everyone have been secured for all citizens.

Refashioning Rawls's theory of justice like this secures the fundamental interests of all citizens. The revised Rawlsian first principle of justice addresses especially the most important concern of poor people to be respected through being safe from harm, having sufficient resources to satisfy their basic needs, and sharing equally in political decision making.

\section{Bibliography}

Alcock, Pete (1993). Understanding Poverty. Houndmills, Basingstoke, Hampshire, The MacMillan Press Ltd.

Arneson, Richard (1999). “Against Rawlsian Equality of Opportunity,” Philosophical Studies, Vol. 93, pp. $77-112$.

Arneson, Richard (1989). "Introduction," Ethics, Vol. 99, No. 4, pp. 695 - 710.

Berlin, Isaiah (1969). Four Essays on Liberty. Oxford, Oxford University Press.

Bohman, James (1996). Public deliberation, Pluralism, complexity, and democracy. Cambridge, Massachusetts, The MIT Press.

Cohen, G.A. (1989). “On the Currency of Egalitarian Justice,” Ethics, Vol. 99, No. 4, pp. 906 - 944.

Cohen, G.A. (2008). Rescuing Justice and Equality. Cambridge, Massachusetts and London, England: Harvard University Press.

DiQuattro, Arthur (1983). "Rawls and Left Criticism," Political Theory, Vol. 11, No. 1, pp. 53 - 78.

Dryzek, John S. (2000). Deliberative democracy and beyond, Liberals, Critics, Contestations. Oxford, Oxford University Press.

Fraser, Nancy (2009). Scales of Justice: Reimagining Political Space in a Globalizing World. New York: Columbia University Press.

Gewirth, Alan (1984). "Practical Philosophy, Civil Liberties, and Poverty." The Monist, Vol. 67, No.4, 549_ 568.

Gilbert, Alan (1989). "Rights and Resources,” The Journal of Value Inquiry, Vol. 23, pp. 227 - 247. Gutmann, Amy \& Dennis Thompson (1996). Democracy and disagreement. Cambridge, Mass., Harvard University Press. 
Halleröd, Björn (2000). “Poverty, Inequality and Health.” In Breadline Europe, The Measurement of Poverty, edited by David Gordon and Peter Townsend, 165 - 187. Bristol, The Policy Press.

Little, Daniel (2003). The Paradox of Wealth and Poverty, Mapping the Ethical Dilemmaf Global

Development. Boulder, Colorado, Westview Press.

Lötter, H.P.P (2008). "Poverty as a Threat to Democratic Values.” Public Affairs Quarterly, Vol. 22, No. 2, $175-193$.

Michelman, Frank I. (1975). "Constitutional Welfare Rights and A Theory of Justice," In Reading Rawls, Critical Studies on Rawls' A Theory of Justice, edited by Norman Daniels, 319 - 347. Oxford, Basil Blackwell.

Mill, John Stuart (2003). Utilitarianism and On Liberty (edited with an introduction by Mary Warnock). Oxford, Blackwell Publishing.

Murphy, Liam (1999). "Institutions and the Demands of Justice," Philosophy and Public Affairs, Vol. 27, No. 4, pp. $251-291$.

Narayan, Deepa \& Patti Petesch (2002). Voices of the Poor, From Many Lands. New York and Washington, Oxford University Press and the World Bank.

O’Neill, Onora (2001). “Agents of Justice.” Metaphilosophy, Vol. 32, No.112, 180-195.

Peffer, Rodney (1990). Marxism, Morality, and Social Justice. Princeton, Princeton University Press.

Pogge, Thomas (2000). “On the Site of Distributive Justice: Reflections on Cohen and Murphy," Philosophy and Public Affairs, Vol. 29, No. 2, pp. 137 - 167.

Rawls, John (1971). A Theory of Justice. Oxford, Oxford University Press.

Rawls, John (2001). Justice as Fairness. A Restatement. (Edited by Erin Kelly). Cambridge, Massachusetts, The Belknap Press of Harvard University Press.

Rawls, John (2007). Lectures on the History of Political Philosophy. (Edited by Samuel Freeman).

Cambridge, Massachusetts, The Belknap Press of Harvard University Press.

Rawls, John (1993). Political Liberalism. Columbia University Press.

Scanlon, T. S. (1975). "Rawls' Theory of Justice.” In Reading Rawls, Critical Studies on Rawls' A Theory of Justice, edited by Norman Daniels, 169 - 205. Oxford, Basil Blackwell.

Schaller, Walter E. (1998). "Rawls, the Difference Principle, and Economic Inequality," Pacific

Philosophical Quarterly, Vol. 79, pp. 368 - 391.

Sen, Amartya (1990). "Justice: Means versus Freedoms," Philosophy and Public Affairs, Vol. 19, No. 2, pp. $111-121$.

Shue, Henry (1980). Basic Rights, Subsistence, Affluence, and U.S. Foreign Policy. Princeton, NJ, Princeton University Press.

Taylor, Robert S. (2003). "Rawls's Defence of the Priority of Liberty: A Kantian Reconstruction," Philosophy and Public Affairs, Vol. 31, No. 3, pp. 246- 271.

Waldron, Jeremy (1986). "John Rawls and the Social Minimum.” Journal of Applied Philosophy, Vol. 3, No. 1 , pp. $21-33$.

World Bank (1990). World Development Report 1990. New York, Oxford University Press.

World Bank (2001). World Development Report 2001. New York, Oxford University Press.

Young, Iris Marion (2003). “Activist challenges to deliberative democracy.” In Debating Deliberative

Democracy, edited by James S. Fishkin \& Peter Laslett, 102 - 120. Malden, MA, USA and Oxford, UK, Blackwell Publishing. 